\title{
General and Specific Combining Ability for Quantitative Characters in Sunflower
}

\author{
Thitiporn Machikowa (Corresponding author) \\ School of Crop Production Technology, Institute of Agricultural Technology \\ Suranaree University of Technology, Nakhon Ratchasima, 30000, Thailand \\ Tel: 66-44-224-579 E-mail: machiko@sut.ac.th
}

Chiraporn Saetang

School of Crop Production Technology, Institute of Agricultural Technology

Suranaree University of Technology, Nakhon Ratchasima, 30000, Thailand

Tel: 66-44-225-006 E-mail: khaijaew_tok@hotmail.com

Kiattisak Funpeng

School of Crop Production Technology, Institute of Agricultural Technology

Suranaree University of Technology, Nakhon Ratchasima, 30000, Thailand

Tel: 66-44-225-006_E-mail: earthkotte@hotmail.com

\begin{abstract}
Seven sunflower (Helianthus annuus L.) inbred lines were crossed in $7 \times 7$ half diallel to obtain $21 \mathrm{~F}_{1}$ hybrids. These lines were used to estimate general combining ability (GCA) and specific combining ability (SCA) effects for yield, head diameter, 1,000-seed weight, plant height and oil content in order to select suitable parents for hybridization and to identify the promising hybrids. The 7 inbred lines and 21 hybrids were planted in a randomized complete block design with three replications at Nakhon Ratchasima, Thailand during 2008-2009. General combining ability and specific combining ability were estimated for seed yield, head diameter, 1,000-seed weight, plant height and oil content. The results revealed that mean squares for GCA were highly significant for head diameter and significant for yield and oil content. Mean squares for SCA were highly significant for 1,000-seed weight and plant height, while those of yield, head diameter and oil content were non-significant. Components of variance showed that the GCA variance was higher than the SCA variance for yield, head diameter and oil content. These results indicated that additive gene action was more important than non-additive gene action for these traits. Inbred line 5A exhibited the highest GCA effects for yield and oil content, followed by the line $2 \mathrm{~A}$. Among all the crosses, $5 \mathrm{~A} \times 2 \mathrm{~A}$ showed the greatest positive SCA effects for $1,000$-seed weight and oil content. Thus, the two inbred lines ( $2 \mathrm{~A}$ and $5 \mathrm{~A})$ revealed good potential to be used as parents for hybrid.
\end{abstract}

Keywords: Helianthus annuus L., Diallel cross, GCA, SCA

\section{Introduction}

Hybrids, due to their high yield potential, are being used throughout the world for increasing the productivity of sunflower. In the breeding program, it is very important to know the combining abilities of inbred lines that are used as parents in hybrids. Plant breeders can take advantage from such information on combining ability for developing high yielding lines and hybrids. Therefore, knowledge of combining ability is essential for selection of suitable parents for hybridization and identification of promising hybrids in breeding program. The diallel method of genetic analysis has been widely used to assess the combining ability of parents in hybrids (Miller et al., 1980; Kadkol et al., 1984; Sherrif et al., 1985). The analysis of diallel cross by the method proposed by Griffing (1956) which partition the total genetic variation into general combining ability (GCA) of the parents and specific combining ability (SCA) of the crosses have been widely used. The GCA is the average performance of a particular inbred in a series of hybrid combinations, whereas SCA refers to the performance of a combination of specific inbred in a particular cross (Sprague and Tatum, 1942). The GCA and SCA variances 
provide an estimation for additive and non-additive gene actions, respectively (Falconer, 1967). Also, combining ability is used in understanding the nature of gene action involved in the expression of quantitative traits and to predict the performance of the progenies. In corn, Bello and Olaoye (2009) found that additive gene action was primarily involved in determining yield and other agronomic traits. In sunflower, various reports indicated the importance of both additive and non-additive genetic variances for yield and other characters (Kaya, 2004; Kaya and Atakisi, 2004; Mijic et al., 2008). Mijic et al. (2008) reported that both GCA and SCA were significant for yield, oil content and oil yield, and estimates of GCA were greater than SCA in magnitude. Marinkovic (1993) reported that GCA effect was more important than SCA for oil content and he found that lines with high GCA gave higher yielding hybrids than lines with low GCA. However, Putt (1966) has reported for his materials that SCA was more important than GCA for seed yield, head diameter and 1,000-seed weight and he reported that generally the higher yielding lines produced the higher yielding hybrid.

This experiment was conducted to estimate GCA and SCA for seed yield, head diameter, 1,000-seed weight, plant height and oil content in 7 inbred lines and to determine perspective parental lines and hybrids of sunflower.

\section{Materials and Methods}

The materials for the present study were seven inbred lines of sunflower developed by Sunflower Breeding Program of Suranaree University of Technology (SUT), Thailand. These inbred lines were designated as 2A, 5A, $7 \mathrm{~A}, 8 \mathrm{~A}, 10 \mathrm{~A}, 11 \mathrm{~A}$ and $12 \mathrm{~A}$. All the inbred lines are of medium to high oil content. A half diallel cross of $7 \times 7$ without reciprocals proposed by Griffing (1956) was used to produce $F_{1}$ hybrids, in 2008 . The seven inbred lines and their 21 hybrids were evaluated at two locations during 2008-2009. The first location was at the experimental farm of the Suranaree University of Technology (SUT farm). The soil type at the site was a Chatturat series (Typic Haplustalfs). The second location was at the National Corn and Sorghum Research Center, Pak Chong. The soil type of this site was Pak Chong series (Oxic Paleustults). The experiment in each site was conducted in a randomized complete block design with three replications. Each plot consisted of 4 rows of $5 \mathrm{~m}$ long and spacing of $0.75 \mathrm{~m}$ between rows and $0.30 \mathrm{~m}$ between plants within row. Two seeds were planted per hill and later thinned to one plant per hill. Fertilizer was applied at the rate of $120 \mathrm{~kg} \mathrm{~N} h a^{-1}, 60 \mathrm{~kg} \mathrm{P}_{2} \mathrm{O}_{5} \mathrm{ha}^{-1}$ and $60 \mathrm{~kg} \mathrm{~K}_{2} \mathrm{O} \mathrm{ha}{ }^{-1}$. Recommended herbicides were used to suppress weeds. Diseases and insects were controlled by regular application of fungicides and insecticides. Data were recorded for seed yield, head diameter, 1,000 -seed weight, plant height and oil content. Analyses of variance were computed for all characters over 2 locations. Griffing Method IV was used to estimate combining ability (Griffing, 1956). The analysis was based on the model by Griffing as:

$$
\mathrm{X}_{\mathrm{ij}}=\mu+\mathrm{g}_{\mathrm{i}}+\mathrm{g}_{\mathrm{j}}+\mathrm{s}_{\mathrm{ij}}
$$

where $X_{i j}=$ the mean phenotypic value; $\mu=$ the general mean; $g_{i}, g_{j}=$ GCA effects of the $i^{\text {th }}$ and $j^{\text {th }}$ parents, respectively; $\mathrm{s}_{\mathrm{ij}}=\mathrm{SCA}$ effect of the cross $\mathrm{i} \times \mathrm{j}$.

The estimates of GCA and SCA of parents and hybrids were obtained as:

$$
\begin{array}{ll}
\text { GCA effects } & g_{i}=\frac{1}{n(n-2)}\left[n X_{1},-2 X_{. .}\right] \\
\text {SCA effects } & \mathrm{s}_{\mathrm{ij}}=\mathrm{X}_{\mathrm{il}}-\frac{1}{\mathrm{n}-2}\left(\mathrm{X}_{\mathrm{l}},+\mathrm{X}_{\mathrm{i}}\right)+\frac{2}{(\mathrm{n}-1)(\mathrm{n}-2)} \mathrm{X}_{. .}
\end{array}
$$

where $X_{i}, X_{\cdot j}=$ means of the $i^{\text {th }}$ and $j^{\text {th }}$ parents, respectively; $X . .=$ grand mean; $n=$ number of parent lines.

\section{Results and Discussion}

There was no interaction between location $\times$ hybrid and the significant difference between locations was not found for all characters (data not shown). Thus, combined ANOVA of combining ability for yield, head diameter, 1,000-seed weight, oil content and plant height over two locations (SUT farm and National Corn and Sorghum Research Center) are presented in Table 1. The mean square for GCA was highly significant for head diameter and significant for seed yield and oil content, indicating the importance of additive gene effect for these traits. The components of variance showed that GCA variance was higher than SCA variance for yield, head diameter and oil content. Furthermore, the ratio of GCA to SCA variance for these traits were higher than 1 . The result indicated for these lines that additive gene action is important for yield, head diameter and oil content. Similar results were reported by others who also found that GCA variance was larger than SCA variance for these traits (Kaya and Atakisi, 2004; Mijic et al., 2008). On the other hand, GCA mean squares were not significant for plant height and 1,000 -seed weight. Mean squares for SCA were highly significant for plant height and 1,000-seed weight, while 
other characters were non-significant. This was similar to other reports (Jan et al., 2005; Khan et al., 2008) which found highly significant SCA effect for 1,000-seed weight. In addition, Khan et al. (2008) reported that SCA variance was greater than GCA variance for 1,000-seed weight, which showed greater manifestation of non-additive gene effect.

The GCA effects for yield and other characters of 7 inbred lines are presented in Table 2. The results revealed that the parents $5 \mathrm{~A}$ and $2 \mathrm{~A}$ were good combiners for yield and oil content. The highest GCA effect for yield was observed for line 5A (8.54), followed by lines 2A (5.26) and 7A (3.44), whereas the lowest GCA value was observed for line 8A (-7.97), followed by lines 10A (-4.96). Significant additive genetic variance for seed yield exists in sunflower (Miller et al., 1980), suggesting that selecting lines on the basis of yield should be useful in developing lines with good combining ability. The lines 5A showed the highest GCA (1.11) for oil content followed by lines 2A (1.08), whereas the lowest GCA value was observed for line 7A (-0.76). The highest GCA effects for head diameter was observed for line 10A (0.60), followed by lines 5A (0.56) and 11A (0.50). Previous research (Sawargaonkar and Ghodke, 2008) also reported positive GCA for yield, head diameter and oil content. In addition, the lines 5A appeared to be good combiners for seed weight (1.01). The preponderance of additive gene action observed for yield, head diameter and oil content indicates that there will be progress in selection form crosses involving inbred $2 \mathrm{~A}$ and $5 \mathrm{~A}$.

The usefulness of a particular cross in exploiting heterosis is judged by the SCA effect of component lines. According to Sprague and Tatum (1942) the SCA is controlled by non-additive gene action. The SCA effect is an important criterion for the evaluation of hybrids. Mean squares for SCA were highly significant for 1,000-seed weight and plant height. The results indicated that non-additive effects were important for these traits. The SCA effects for 1,000-seed weight, plant height, yield and other characters of crosses are presented in Table 3 . The cross of $5 \mathrm{~A} \times 2 \mathrm{~A}$ showed the highest SCA effect for 1,000-seed weight (2.67), followed by the crosses of $12 \mathrm{~A} \times 5 \mathrm{~A}$ (1.94) and $7 \mathrm{~A} \times 2 \mathrm{~A}(1.31)$. In this research, increasing plant height was considered to be undesirable but increasing yield, oil content, 1,000-seed weight and head diameter were desirable. Also, the highest negative SCA effect for plant height was observed for the cross $12 \mathrm{~A} \times 2 \mathrm{~A}(-8.80)$. The importance in SCA effect was not found for yield, head diameter and oil content. However, the highest specific combination for seed yield was $12 \mathrm{~A} \times 2 \mathrm{~A}(12.32)$, followed by $10 \mathrm{~A} \times 5 \mathrm{~A}(8.96)$. Among the crosses, $8 \mathrm{~A} \times 7 \mathrm{~A}$ showed the greatest positive SCA effect for head diameter (1.22), followed by $5 \mathrm{~A} \times 2 \mathrm{~A}(0.98)$. The best specific combinations for oil content were $10 \mathrm{~A} \times 8 \mathrm{~A}(1.94)$, followed by $5 \mathrm{~A} \times 2 \mathrm{~A}(1.45)$ and $8 \mathrm{~A} \times 7 \mathrm{~A}(1.22)$.

\section{Conclusion}

Seed yield, head diameter and oil content are important traits in sunflower. The results showed that for this set of inbred lines GCA effect gave greater proportion of variance than SCA effect, suggesting that additive gene effects were found governing the inheritance of yield, head diameter and oil content. Among the lines, 2A and 5A were found to be good general combiners for yield, oil content and 1,000-seed weight and also involved in promising cross combinations. The lines 5A and 10A exhibited maximum GCA effect for head diameter. Therefore, the performances of a single cross progeny can be predicted on the basis of GCA, because SCA mean squares were not significant. Among the crosses, $5 \mathrm{~A} \times 2 \mathrm{~A}$ had positive significant SCA value for seed yield, oil content, 1,000 -seed weight and head diameter, which are the desired traits for better population. Therefore, the lines $2 \mathrm{~A}$ and $5 \mathrm{~A}$ have desirable agronomic traits and could be used as parents for hybrid due to their high performance and their hybrid having one of the highest SCA effect in yield, 1,000-seed weight and oil content.

\section{Acknowledgement}

The authors gratefully acknowledge the financial support to this research by Office of National Research Council of Thailand.

\section{References}

Bello, O.B. \& Olaoye, G. (2009). Combining ability for maize grain yield and other agronomic characters in a typical southern guinea savanna ecology of Nigeria. Afr. J. Biotechnol., 8, 2518-2522.

Falconer, S.P. (1967). Introduction to quantitative genetics. New York: The Ronald Press Company.

Griffing, B. (1956). Concept of general and specific combining ability in relation to diallel crossing system. Aust. J. Biol. Sci., 9, 463-493.

Jan, M., Farhatullah, Raziudin \& Hassan, G. (2005). Combining ability analysis in sunflower (Helianthus annuus L.). Pak. J. Biol. Sci., 8, 710-713. 
Kadkol, G.P., Anand, I.J. \& Sharma, R.P. (1984). Combining ability and heterosis in sunflower. Indian J. Genet., 44, 447-451.

Kaya, Y. (2004). Determining combining ability in sunflower (Helianthus annuus L.). Turk. J. Agric. For., 29, 243-250.

Kaya, Y. \& Atakisi, I.K. (2004). Combining ability analysis of some yield characters of sunflower (Helianthus annuus L.). Helia, 27, 75-84.

Khan, H., Rahman, H., Ahmad, H., Ali, H., Inamullah \& Alam, M. (2008). Magnitude of combining ability of sunflower genotypes in different environments. Pak. J. Bot., 40, 151-160.

Marinkovic, R. (1993). Combining ability of some inbred sunflower (H. annuus L.) lines. Indian J. of Genet, 5, 299-304.

Mijic, A., Kozumplik, V., Kovacevic, J., Liovic, I., Krizmanic, M., Duvnjak, T., Maric, S., Horvat, D., Simic, G. \& Gunjaca, J. (2008). Combining abilities and gene effects on sunflower grain yield, oil content and oil yield. Period biol., 110, 277-284.

Miller, J.F., Hammond, J.J. \& Roath, W.W. (1980). Comparison of inbred vs. single-cross testers and estimation of genetic effects in sunflowers. Crop Sci., 20, 703-706.

Putt, E.D. (1966). Heterosis, combining ability and predicted synthetics from a diallel cross in sunflowers (Helianthus annuus L.). Can. J. Plant Sci., 46, 59-67.

Sawargaonkar, S.L. \& Ghodke, M.K. (2008). Heterosis in relation to combining ability in restorer lines of sunflower. Helia, 31, 95-100.

Sherrif, N.M., Appadurai, R. \& Rangasamy, M. (1985). Combining ability in sunflower. Indian J. Agric. Sci., 55, 315-318.

Sprague, G.F. \& Tatum, L.A. (1942). General vs specific combining ability in single crosses of corn. $J$. American Soc. Agron., 34, 923-932.

Table 1. Mean squares for general (GCA) and specific combining ability (SCA) of 21 hybrids for yield and other characters

\begin{tabular}{|c|c|c|c|c|c|c|}
\hline Sources & df & Yield & $\begin{array}{c}\text { Head } \\
\text { diameter }\end{array}$ & $\begin{array}{c}\mathbf{1 , 0 0 0 - s e e d} \\
\text { weight }\end{array}$ & Plant height & $\begin{array}{c}\text { Oil } \\
\text { content }\end{array}$ \\
\hline GCA & 6 & $11,064.12^{*}$ & $2.78^{* *}$ & 2.25 & 14.97 & $4.98^{*}$ \\
\hline SCA & 14 & $3,833.36$ & 0.59 & $2.58^{* *}$ & $39.94^{* *}$ & 1.58 \\
\hline error & 80 & $4,405.02$ & 0.37 & 0.81 & 15.13 & 2.18 \\
\hline GCA/SCA & & $3: 1$ & $5: 1$ & $1: 1$ & $0.4: 1$ & $3: 1$ \\
\hline
\end{tabular}

*, ** Significant at 0.05 and 0.01 probability levels, respectively.

Table 2. General combining ability (GCA) for yield and other characters of 7 inbred lines

\begin{tabular}{|c|c|c|c|c|c|}
\hline Lines & Yield & Head diameter & $\mathbf{1 , 0 0 0 - s e e d ~ w e i g h t ~}$ & Plant height & Oil content \\
\hline $2 \mathrm{~A}$ & $5.26^{* *}$ & $-0.66^{* *}$ & 0.06 & $1.35^{*}$ & $1.08^{* *}$ \\
\hline $5 \mathrm{~A}$ & $8.54^{* *}$ & $0.56^{* *}$ & $1.01^{* *}$ & -0.65 & $1.11^{* *}$ \\
\hline $7 \mathrm{~A}$ & $3.44^{*}$ & $-0.56^{* *}$ & -0.13 & $-1.62^{* *}$ & $-0.76^{* *}$ \\
\hline $8 \mathrm{~A}$ & $-7.97^{* *}$ & $-0.75^{* *}$ & -0.10 & -0.29 & $-0.69^{* *}$ \\
\hline $10 \mathrm{~A}$ & $-4.96^{* *}$ & $0.60^{* *}$ & $0.29 *$ & $2.07^{* *}$ & 0.34 \\
\hline $11 \mathrm{~A}$ & $-3.71^{*}$ & $0.50^{* *}$ & $-0.60^{* *}$ & $-1.62^{* *}$ & $-0.61^{* *}$ \\
\hline $12 \mathrm{~A}$ & -0.59 & $0.30^{*}$ & $-0.62^{* *}$ & 0.77 & $-0.47^{*}$ \\
\hline
\end{tabular}

$*$,** Significant at 0.05 and 0.01 probability levels, respectively. 
Table 3. Specific combining ability (SCA) for yield and other characters of 21 hybrids

\begin{tabular}{|c|c|c|c|c|c|}
\hline Hybrids & Yield & $\begin{array}{c}\text { Head } \\
\text { diameter }\end{array}$ & $\begin{array}{c}\text { 1,000-seed } \\
\text { weight }\end{array}$ & Plant height & Oil content \\
\hline $5 \mathrm{~A} \times 2 \mathrm{~A}$ & 6.91 & $0.98 * *$ & $2.67 * *$ & $-6.60 * *$ & $1.45^{* *}$ \\
\hline $7 \mathrm{~A} \times 2 \mathrm{~A}$ & 5.64 & -0.28 & $1.31 * *$ & 0.57 & $1.08^{*}$ \\
\hline $8 \mathrm{~A} \times 2 \mathrm{~A}$ & -7.69 & 0.38 & -0.37 & $9.80^{* *}$ & $-1.74 * *$ \\
\hline $10 \mathrm{~A} \times 2 \mathrm{~A}$ & $-16.67 * *$ & 0.09 & $-0.98 * *$ & -0.53 & -0.77 \\
\hline $11 \mathrm{~A} \times 2 \mathrm{~A}$ & -0.51 & $-0.91 * *$ & 0.56 & $5.57 * *$ & 0.43 \\
\hline $12 \mathrm{~A} \times 2 \mathrm{~A}$ & $12.32 * *$ & -0.25 & $-3.19 * *$ & $-8.80 * *$ & -0.44 \\
\hline $7 \mathrm{~A} \times 5 \mathrm{~A}$ & -4.05 & -0.02 & $-2.56 * *$ & -2.20 & -0.06 \\
\hline $8 \mathrm{~A} \times 5 \mathrm{~A}$ & 6.87 & $-0.73 * *$ & -0.33 & $3.20 *$ & $-1.06^{*}$ \\
\hline $10 \mathrm{~A} \times 5 \mathrm{~A}$ & 8.96 & 0.34 & -0.39 & -1.47 & -0.11 \\
\hline $11 \mathrm{~A} \times 5 \mathrm{~A}$ & -6.32 & $0.62 * *$ & $-1.34 * *$ & -0.87 & -0.62 \\
\hline $12 \mathrm{~A} \times 5 \mathrm{~A}$ & $-12.36^{* *}$ & $-1.18 * *$ & $1.94 * *$ & $7.93 * *$ & 0.40 \\
\hline $8 \mathrm{~A} \times 7 \mathrm{~A}$ & $-13.37 * *$ & $1.22 * *$ & 0.17 & -0.13 & $1.22 *$ \\
\hline $10 \mathrm{~A} \times 7 \mathrm{~A}$ & 3.83 & $-0.89 * *$ & $0.79 *$ & $9.70 * *$ & -0.63 \\
\hline $11 \mathrm{~A} \times 7 \mathrm{~A}$ & 1.77 & 0.01 & $0.84 *$ & $-4.20 *$ & $-1.17^{*}$ \\
\hline $12 \mathrm{~A} \times 7 \mathrm{~A}$ & 6.17 & -0.04 & -0.57 & $-3.73^{*}$ & -0.45 \\
\hline $10 \mathrm{~A} \times 8 \mathrm{~A}$ & 6.31 & -0.41 & -0.09 & $-8.40 * *$ & $1.94 * *$ \\
\hline $11 \mathrm{~A} \times 8 \mathrm{~A}$ & 1.29 & $-0.51 *$ & -0.35 & $-2.97^{*}$ & -0.96 \\
\hline $12 \mathrm{~A} \times 8 \mathrm{~A}$ & 6.59 & 0.05 & $0.97 *$ & -1.50 & 0.59 \\
\hline $11 \mathrm{~A} \times 10 \mathrm{~A}$ & 5.53 & 0.13 & 0.05 & -1.47 & 0.99 \\
\hline $12 \mathrm{~A} \times 10 \mathrm{~A}$ & $-10.95^{*}$ & $0.76^{* *}$ & 0.62 & 2.17 & $-1.43^{* *}$ \\
\hline $12 \mathrm{~A} \times 11 \mathrm{~A}$ & -3.26 & $0.66^{* *}$ & 0.23 & $3.93 *$ & $1.32 *$ \\
\hline
\end{tabular}

*, ** Significant at 0.05 and 0.01 probability levels, respectively. 